\title{
Vyřešil Hans Albert problémy Popperova kritického racionalismu? ${ }^{1}$
}

\section{Did Hans Albert Solve the Problems of Popper's Critical Rationalism?}

\author{
Jitka Paitlová \\ Katedra filozofie \\ Filozofická fakulta \\ Západočeské univerzity v Plzni \\ Sedláčkova 19, 30614 Plzeň \\ paitlova@kfi.zcu.cz
}

\begin{abstract}
Abstrakt/Abstract
Kritický racionalismus je v české akademické diskusi spojován především se jménem sira Karla R. Poppera. Cílem tohoto článku je komparativně rozšiřit tento obraz prostřednictvím myšlenek Hanse Alberta, Popperova následovníka v německé jazykové oblasti. Konkrétně bude diskutována problematika rozlišení kontextu objevu a kontextu zdůvodnění. Na základě vybraných problémů, s nimiž se Popper nedokázal zcela vypořádat, bude ukázáno, jak tyto problémy do své koncepce involvuje a jak je řeší Albert. Zajímavý na tomto srovnání je především fakt, že Albert pojímá původně filosoficko-vědní problémy v širším filosofickém rámci. Díky tomu se mu podařilo uchopit kritický racionalismus - jak sám Popper uznal - s odstupem a v nových souvislostech.
\end{abstract}

In the Czech academic environment, the critical rationalism is associated above all with the name of Sir Karl R. Popper. The aim of this paper is to comparatively extend this view via thoughts of Popper's German follower Hans Albert. Specifically, the issue of the distinction between context of discovery and context of justification will be discussed here. Against the background of selected problems, which Popper did not adequately solve, I will demonstrate how Albert involves these problems in his own conception and how he solves them. The interesting fact about this comparison is that Albert approaches the originally philosophical-scientific problems in a wider philosophical context. Thanks to this wider context he grasps the critical rationalism from a distance and in new connections, as Popper accepted himself.

„Můj milý Hansi, právě jsem přečetl Tvoji knihu [Traktat über kritische Vernunft]. Jsem opravdu nadšen. [...] Nikdy bych takovouto knihu nenapsal: k tomu by mi chyběl odstup; zadruhé Tvé bohaté vědění - Tvá znalost literatury (ačkoli tento bod je méně důležitý). [...] Onen odstup je řešením problému - toho či onoho problému -, které mi bylo zatěžko. Proto jsem byl

${ }^{1}$ Studie vznikla za podpory grantového systému Západočeské univerzity v Plzni v rámci projektu č. SGS-2016-009. 
- a jsem - zcela neschopný takového souvislého vylíčení. Zároveň jsem ale věděl, že takové souvislosti existují; ale nevěřil jsem, že je někdo jiný může opravdu jasně vidět - neřkuli jasně vylíčit. [...] Velmi srdečně Tě zdraví Tvůj starý Karl.“2

To napsal Popper v říjnu 1968, nedlouho poté, co vyšel stěžejní spis Hanse Alberta: Traktát o kritickém rozumu. Hans Albert není v současné české filosofické diskuzi již zcela neznámým zástupcem kritického racionalismu. ${ }^{3}$ Rozšiřruje tak zástup vlivných Popperových anglosaských následovníků jako W. W. Bartley, A. Musgrave, J. Agassi, D. Miller, kteří jsou u nás také postupně etablováni do diskuze. ${ }^{4}$ Cílem předkládané studie je komparativně uchopit původní Popperovy kriticko-racionalistické názory a systematizované pojetí kritického racionalismu právě Hanse Alberta, který je Popperovým nejvýraznějším následovníkem v německojazyčné oblasti. Na základě vybraných problémů, s nimiž se podle mého názoru Popper nedokázal dokonale vypořádat, bude ukázáno, jak tyto problémy do své koncepce involvuje a jak se je pokouší řešit právě Hans Albert. Zajímavý na tomto srovnání je především fakt vyplývající z úvodní citace, totiž že Albert pojímá původně filosoficko-vědní problémy v širším filosofickém rámci, díky čemuž se mu podařilo uchopit kritický racionalismus - jak sám Popper uznal - s odstupem a v nových souvislostech.

\section{Kritika Popperovy eliminace kontextu objevu z epistemologie}

V první části této stati chci navrhnout kritiku Popperovy eliminace kontextu objevu z epistemologie. $^{5} \mathrm{Na}$ vybraných problémech (problém indukce, verifikace a psychologismu) se pokusím ukázat, že na jednu stranu toto eliminační řešení sice umožňuje Popperovi vyhnout se (alespoň z větší míry) některým problémům, na druhou stranu jde podle mého názoru o redukcionismus, který není v intencích kritického racionalismu. V žádném případě mi tedy nejde o vyvrácení Popperova řešení oněch problémů, nýbrž chci spíše poukázat na určité slabiny, které toto řešení obsahuje. Zejména pak Popperovo řešení problému psychologismu se zdá být z pohledu samotného kritického racionalismu nedostatečné.

Nejdříve krátce shrnu Popperova hlavní stanoviska, jak je představil ve spise Logika védeckého zkoumání. Svoji pozici zde postavil především na striktním odmítnutí principu indukce a veškerých z ní vyplývajících pravděpodobnostních variant.

\footnotetext{
${ }^{2}$ Morgenstern \& Zimmer (2005, s. 109-110).

${ }^{3}$ Např. Paitlová (2015), Funda (2015).

${ }^{4}$ Např. Sloup (2015a).

${ }^{5}$ Přičemž chci hned na začátku zdůraznit, že $\mathrm{v}$ této stati budu za účelem výše vytyčené komparace vycházet výhradně ze tř́ Popperových spisů: Logika vědeckého zkoumání (1934), Domněnky a vyvrácení (1963) a Objektivní poznání (1972), které vyšly před nebo nedlouho po Albertově Traktátu o kritickém rozumu (1968).
} 
V návaznosti na Huma konstatuje, že z logického hlediska nelze z platných singulárních tvrzení vyvodit platná univerzální tvrzení, nebot’ „bez ohledu na to, kolik případů bílých labutí jsme pozorovali, neospravedlňuje to závěr, že všechny labutě jsou bílé“ “. ${ }^{6} \mathrm{~V}$ tomto smyslu hovoří Popper později o takzvaném logickém problému indukce, vedle něhož staví ještě takzvaný psychologický problém indukce, který souvisí s našimi vrozenými očekáváními pravidelností ve světě. ${ }^{7}$

Podle Poppera nelze induktivní inferenci logicky zdůvodnit, „teorie nejsou tudíž nikdy empiricky verifikovatelné“, to znamená, že teorie nelze definitivně justifikovat ve smyslu verifikace či pozitivní konfirmace, resp. probability. ${ }^{8}$ Dále poukazuje na to, že s indukcí, která vychází z formulace pozorovaných faktů, je navíc spojen takzvaný problém psychologismu:

„Víra v induktivistickou logiku pochází totiž převážně ze směšování psychologických problémů s problémy epistemologickými. “9

Tím je míněno směšování kontextu objevu a kontextu zdůvodnění. Popper tyto dva kontexty ostře rozlišuje a především je určuje za předmět zcela odlišných disciplín: kontext objevu (tj. proces vymýšlení nové ideje) odsune do oblasti tzv. psychologie poznání (resp. empirické psychologie), zatímco kontext zdůvodnění (tj. metody a výsledky logického zkoumání oné ideje) učiní předmětem své teorie poznání, která spočívá v logické analýze vědecké metody. ${ }^{10}$ Právě na kontext zdůvodnění pak Popper uplatní svoji hypoteticko-deduktivní metodu falzifikace spočívající na modu tollens.

Popperem navržená alternativa, falzifikace, založená na deduktivním testování předložených hypotéz, je metoda, která z pravdivosti mnoha singulárních tvrzení neodvozuje pravdivost, resp. pravděpodobnost univerzálních tvrzení (jak to činí metoda verifikace), nýbrž z nepravdivosti i jednoho singulárního tvrzení usuzuje na nepravdivost univerzálního tvrzení. Proto „,nemohou být ve vědě žádná konečně platná tvrzení“, a proto právě falzifikace je podle Poppera jedinou možnou metodou, která na rozdíl od induktivní verifikace nevede k dogmatismu a stagnaci myšlení, nýbrž k pokroku a růstu poznání. ${ }^{11}$

Nechci zde nijak vyvracet Popperovu poměrně odvážnou a velmi promyšlenou koncepci kriticko-racionalistické metodologie vědy. Avšak domnívám se, že problém indukce, verifikace a psychologismu nelze $\mathrm{z}$ epistemologie, respektive teorie vědy nikdy

\footnotetext{
${ }^{6}$ Popper (1997, s. 3-4).

${ }^{7}$ Srv. Popper (1993).

${ }^{8}$ Popper (1997, s. 19).

${ }^{9}$ Tamtéž, s. 7.

${ }^{10}$ Srv. Popper (1997, s. 8). Např. Preston (1994, s. 314-315) ukazuje, že Popper ztotožňuje epistemologii teorií empirické metody, teorií zkušenosti, logikou vědeckého bádání, teorií teorií (theory of theories) a metodologií, přičemž tvrdí, že toto Popperovo pojetí epistemologie a metodologie je ,značně zmatené“.

${ }^{11}$ Popper (1997, s. 27).
} 
zcela eliminovat - a to právě z kriticko-racionalistického hlediska: jinak by totiž sama teorie poznání či teorie vědy sklouzla do dogmatismu a oslabila svoji explanační sílu -, a nadto zde chci poukázat na fakt, že Popperova koncepce tyto fenomény v určité podobě bud' obsahuje (psychologický problém indukce, verifikace), nebo se jim tendenčně vyhýbá (psychologismus).

Začnu problémem indukce, prričemž se zaměřím především na jeho psychologickou formu (logický problém indukce souvisí s verifikací, která bude řešena posléze). ${ }^{12}$ Psychologický problém indukce se týká kontextu objevu vědecké teorie. Znovu je třeba zopakovat a zdůraznit, že Popper, protože se chce tomuto problému vyhnout, eliminuje v Logice kontext objevu ze své logiky vědy a odsouvá jej do oblasti psychologie (tuto eliminaci kritizuji níže). Ve svých pozdějších spisech však Popper řeší psychologický problém indukce v rámci své koncepce evoluční epistemologie. Jde o problém, čím poznání začíná, a to $\mathrm{v}$ tomto případě $\mathrm{z}$ hlediska historicko-vědního. Popper tvrdí, že poznání „,nemůže vycházet z pozorování“ (to znamená, že je deduktivní povahy) a zároveň, že pokrok našeho vědění spočívá především $\mathrm{v}$ „modifikaci dřívějšího vědění“, které však, jak se ukáže, musí částečně induktivně vycházet ze zkušenosti, což vede k určité konfúzi. ${ }^{13}$

Popper tvrdí, že máme vrozenou tendenci očekávat všude zákonitosti, přičemž tato tendence vede $\mathrm{k}$,psychologickému fenoménu dogmatického myšlení“; naproti tomu staví kritický postoj, který „,připouští modifikaci názorů a pochybnosti a požaduje jejich přezkoušení“. ${ }^{14}$ Rozlišuje takzvanou dogmatickou a kritickou fázi učení, respektive poznání a říká, že ,nemůže existovat žádná kritická fáze, jíž by nepředcházela fáze dogmatická“ - v dogmatické (předvědecké) fázi se něco formuje (očekávání, pravidelné chování), na základě čehož pak může v rámci kontextu zdůvodnění začít kritická eliminace chyb. ${ }^{15}$ Parusniková pak poukazuje na to, že jednak je spojení mezi indukcí a dogmatismem ,základním ideologickým tématem Popperovy filosofie“ a jednak je ona silná potřeba pravidelnosti ,induktivní dispozicí“. ${ }^{16}$

To však vede k problému v Popperově pozdějším evolučním pojetí epistemologie, nebot' i z historicko-vědního hlediska stojí podle Poppera na počátku poznání nevědomá vrozená očekávání, avšak tato očekávání musí být už ze samotné svojí definice

${ }^{12}$ V této souvislosti poukazuje na zajímavé rozlišení Grattan-Guinness (2004, s. 109), který tvrdí, že původní Humova formulace problému indukce (Může být tvrzení, že univerzální teorie je pravdivá, empiricky zdůvodněno?) byla ryze epistemologického charakteru, zatímco Popperova formulace (Může být preference ohledně pravdivosti či nepravdivosti konkurenčních univerzálních teorií empiricky zdůvodněna?) má charakter ryze metodologický. To souvisí s níže zmíněným problémem redukce teorie poznání na logiku vědy, což kritizuje např. Preston (1994, s. 318), který rozlišuje deskriptivní teorii poznání a normativní metodologii.

${ }_{13}^{13}$ Popper (2009, s. 43).

${ }^{14}$ Tamtéž, s. 73-74.

${ }^{15}$ Popper (1995, s. 50-51).

${ }^{16}$ Parusniková (2003, s. 61). 
induktivní povahy, nebot' se jedná o očekávání pravidelností na základě přenosu minulé zkušenosti do budoucnosti. A pokud Popper explicitně tvrdí, že dogmatická fáze (tj. poznání založené na indukci, resp. očekáváních induktivního charakteru) vždy předchází fázi kritické - což je myšleno především z hlediska historicko-vědního (jako fáze předvědecká a fáze vědecká), ale mohlo by to být částečně pochopeno též $\mathrm{z}$ hlediska metodologického (jako kontext objevu a zdůvodnění vědecké teorie) -, pak tím přeci indukci do své teorie de facto implicitně zahrnuje. ${ }^{17}$

Je však třeba říci, že to Popperovu koncepci - v níž kontext objevu hned zpočátku eliminuje a jasně odděluje ,psychologické aspekty problému od aspektů logických“ nijak neohrožuje. Ovšem oslabuje to jeho tolik striktní odmítnutí indukce. Ukazuje se, že Popperovo odmítnutí indukce ve smyslu ,neexistuje nic takového jako indukce“, ${ }^{18}$ je plausibilní právě a pouze za podmínky, že je vztaženo na logiku, a proto by mělo být omezeno na tvrzení, že „nepřijímá induktivní logiku“. ${ }^{19}$ Pokud vyjdeme za hranice Popperovy logiky vědy, lze podotknout, že prrinejmenším pragmatická indukce je nedomyslitelnou součástí vědecké, resp. lidské poznávací praxe vůbec. ${ }^{20}$

Nyní přejdu k problému verifikace a s ním spojenému logickému problému indukce. Někteří autoři ${ }^{21}$ poukazují na fakt, že v rámci kontextu zdůvodnění není falzifikace možná bez předchozí verifikace observačních tvrzení, která mají vyvrátit předloženou hypotézu. V této souvislosti chci však zdůraznit, že tento fakt hned v první kapitole své Logiky přiznává, když popisuje deduktivní testování teorií: Z předložené teorie (hypotézy) odvozujeme singulární tvrzení a následně musíme rozhodnout o těchto tvrzeních na základě porovnání s výsledky experimentů. Dále explicitně píše:

„Je-li rozhodnutí pozitivní, to jest, ukážou-li se být singulární závěry přijatelné, nebo verifikované, pak tato teorie, aspoň pro tuto chvíli, prošla testy. “22

\footnotetext{
${ }^{17}$ Podle Parusnikové to jednoznačně platí u fylogeneze (tedy z hlediska historicko-vědního), zatímco u ontogeneze (zhlediska metodologického) je možné přistoupit na Popperovo stanovisko: „Vědění je tak fylogeneticky a posteriori, ale ontogeneticky a priori.“ Parusniková (2009, s. 65).

${ }^{18}$ Popper (1997, s. 19). Např. Hahn (1982, s. 30) poukazuje na Popperovo tvrzení, že indukce je mýtus, protože není faktem ani psychickým, ani každodenního života, ani vědeckého postupu.

${ }^{19}$ Popper (1997, s. 13).

${ }^{20}$ Srv. např. Sloup (2015b, s. 125): „Vykázáním indukce ze sféry všedního usuzování se Popper dostal do sporu s naší každodenní zkušeností, kdy indukci dlouho-době důvěřujeme a považujeme ji za spolehlivou metodu pro orientaci ve světě. Vytvoření kontrastu mezi každodenností a vědeckou praxí by Popperovi umožnilo ponechat indukci, reprezentovanou netematizovanou vírou $\mathrm{v}$ princip uniformity přírody, $\mathrm{v}$ okruhu rozhodnutí, která nepotřebují oporu v logicky pevné a platné dedukci. $\mathrm{V}$ rámci vědy může následně Popper podržet důraz na čistě deduktivním založení vědecké metody.“

${ }^{21}$ Např. Parusniková (2007, s. 46): „Řečeno ještě ostřeji, falzifikace není možná bez verifikace, ale verifikaci Popper zakazuje.“

${ }^{22}$ Popper (1997, s. 10).
} 
Takováto teorie se dočasně osvědčila, což nazývá koroborací.

$\mathrm{Na}$ Popperovu obranu je proto třeba říci, že si byl tohoto problému již od začátku evidentně vědom. Určitý druh verifikace (na té nejnižší úrovni testování) přiznává, ale dodává, že jím navržená procedura neobsahuje ,nic, co by se podobalo induktivní logice“, nebot' z pravdivosti singulárních tvrzení neusuzuje na pravdivost, nýbrž nepravdivost teorií (hypotéz) - tento jev nazývá asymetrií mezi verifikací a falsifikací. ${ }^{23}$ I zde se tedy Popper dokáže problému verifikace vyhnout, avšak opět pouze za určitých podmínek, totiž že verifikována nejsou v jeho logice vědy nikdy tvrzení univerzální, nýbrž pouze tvrzení singulární. To znamená, že v tomto smyslu se Popper v rámci kontextu zdůvodnění skutečně vyhýbá i logickému problému indukce, pokud je tato definována jako odvození pravdivosti univerzálního tvrzení z pravdivosti singulárních tvrzení.

A konečně krátce k problému psychologismu. Popper sice, jak bylo řečeno výše, odmítá psychologismus prostřednictvím eliminace kontextu objevu, avšak podle mého názoru se v rámci kontextu zdůvodnění ani on reminiscencí psychologismu nedokázal vyvarovat. Mám na mysli výše zmíněné „rozhodnutí“ ohledně pravdivosti základních tvrzení prostřednictvím experimentu. Podle Poppera spočívá objektivita vědeckých tvrzení „,ve faktu, že mohou být intersubjektivně testována“. ${ }^{24}$ Rozhodnutí o základních tvrzeních by tedy mělo vycházet $\mathrm{z}$ intersubjektivního konsensu - to samé by ovšem mohli říci novopozitivisté o empirickém daném. Tomuto problému se lze však těžko vyhnout, alespoň do té doby, dokud vědu budou dělat ,,jen“ lidé. Domnívám se, že to jasně demonstruje limity Popperova př́stupu. I přes rozlišení psychologických a logicko-metodologických aspektů, i přes všechna omezení na pouhou logiku vědy koncentrovanou na kontext zdůvodnění, se ukazuje, že minimálně psychologickému prvku rozhodnutí a s ním spojené verifikaci (i když pouze na úrovni základních či singulárních tvrzení) se ani v logice vědy nevyhneme.

$\mathrm{Na}$ závěr této části věnované Popperovi chci proto nejprve na jeho obranu zdůraznit, že si Popper byl výše zmíněných problémů vědom a učinil potřebná eliminační opatření, aby se těmto problémům vyhnul, což je patrné již z jím vytyčeného obecného cíle, totiž analyzovat právě a pouze logiku vědeckého bádání. Avšak tvrdím, že pokud by Popper i v širším smyslu (v rámci kritického racionalismu) definitivně a jednou provždy eliminoval nějaký fenomén (at' už indukce, verifikace, psychologismu či jiný), pak by se sám postavil proti kriticko-racionalistickému požadavku pouhého návrhového charakteru a dočasnosti všech závěrů, a sklouzl by do jím tolik zavrhovaného a obávaného dogmatismu. I když svoji teorii poznání redukoval pouze na

\footnotetext{
23 Tamtéž, s. 20.

24 Tamtéž, s. 24.
} 
logiku vědy ${ }^{25}$ a jejím předmětem učinil kontext zdůvodnění, ukázalo se, že ani v tomto omezeném rámci se určitým problémům v oslabené formě nevyhne (viz problém verifikace a psychologismu). Navíc touto redukcí snižuje explanační sílu své teorie, na které si tolik zakládá. A nadto je třeba brát v potaz fakt, že věda není čistě logickým postupem, nýbrž velmi sofistikovaným druhem lidské praxe, na níž se předpoklad falibilismu musí vztahovat ještě př́sněji, než na méně sofistikované lidské činnosti. Právě to v rámci své koncepce kritického racionalismu zdůrazňuje a rozvádí Popperův následovník v německé jazykové oblasti, filosof, sociolog a ekonom, Hans Albert, přičemž - jak už víme - se mu za to od samotného Poppera dostalo pozitivního uznání. ${ }^{26}$

\section{Albertovo přemostění propasti mezi kontextem objevu a kontextem zdůvodnění}

Z výše řečeného vyplývá, že zejména $\mathrm{z}$ hlediska samotného kritického racionalismu nepovažuji za správné, že Popper vyloučil kontext objevu z epistemologie. Ve snaze eliminovat psychologismus stanovil za předmět teorie poznání, respektive logické analýzy vědecké metody, pouze kontext zdůvodnění, zatímco kontext objevu odsunul zcela stranou (do oblasti psychologie poznání). Jestliže ale Popper teorii poznání ztotožňuje jen s „metodami a výsledky logického zkoumání“ vědeckých teorií, jedná se podle mě o scientistický redukcionismus, který omezuje teorii poznání toliko na logiku, a v tomto smyslu se tím staví na stejnou úroveň jako Popperem kritizovaný novopozitivismus, pro který sice nebyla cílem logická analýza metody vědy, nýbrž logická analýza jazyka vědy, obojí ale zůstávají na úrovni logiky. ${ }^{27}$ Novopozitivismus tak ztroskotal na psychologismu či fenomenalismu empirického daného, resp. protokolárních vět, které měly prostřednictvím empirického kritéria smyslu vést naopak ke zcela objektivnímu poznání. Popper se sice eliminací psychologismu prostřednictvím vyloučení kontextu objevu tomuto problému vyhýbá, na druhou stranu tím však zároveň nepřijatelně redukuje oblast zájmu epistemologie.

Pokud se podíváme na koncepci kritického racionalismu Hanse Alberta, lze vidět posun, který Albert v řešení těchto problémů učinil. Nutno podotknout, že to je vždy v rámci a intencích kritického racionalismu, jak jej ustavil Popper. Někdy se může zdát, že Albert říká jinými slovy či obšírněji nebo systematičtěji to samé, co Popper. Podle mého názoru lze však v Albertově koncepci kritického racionalismu vidět určitý přesah, který uznal i sám Popper (jak bylo demonstrováno v úvodní citaci). Albert se vůči

\footnotetext{
${ }^{25}$ Tuto redukci kritizuje např. Preston (1994, s. 318), který mimo jiné poukazuje na skutečnost, že „teorie poznání je deskriptivní“, zatímco metodologie je normativní disciplínou. Také Rivadulla (1987, s. 181) upozorňuje na „napjatou situaci mezi teorií poznání a logikou vědy“ v Popperově filosofii.

${ }^{26}$ Srv. Morgenstern \& Zimmer (2005).

${ }^{27}$ Popper (1997, s. 8). Tento redukcionismus je nejvíce signifikantní právě v Popperově Logice, v pozdějších spisech Popper oblast zájmu teorie poznání postupně rozšiřuje.
} 
Popperovi sice nikdy explicitně kriticky nevymezuje stylem, že by něco tvrdil „,na rozdíl od Poppera“, ${ }^{28}$ přesto je v jeho spisech rozvedených mnoho témat, která Popper pouze tematizoval, ale nedokázal uspokojivě rozvést. Už ve svém Traktat über kritische Vernunft Albert zaprvé začleňuje rozhodnutí (ve smyslu iracionálního prvku kontextu objevu) do epistemologie tím, že překonává novopozitivistickou (a jak bylo naznačeno výše i popperovskou) propast mezi rozhodnutím (kontextem objevu) a poznáním (kontextem zdůvodnění), čímž de facto začleňuje Popperem eliminovaný kontext objevu do epistemologie; a zadruhé upravuje a rozvádí Popperem pouze zmíněné Friesovo trilema týkající se kontextu zdůvodnění jako tzv. trilema Münchhausenovo, které se stalo modelovým příkladem problému epistemologického zdůvodnění, jenž je v kritickém racionalismu nahrazen principem kritiky.

Zaprvé: Kontext objevu. Albert nejenže bezprostředně přiznává, že „za vším poznáním stojí rozhodnutí“, ale nadto nehodlá rozhodnutí (ve smyslu kontextu objevu) $\mathrm{z}$ epistemologie eliminovat (jako to ve výše nastíněném smyslu udělal Popper), nýbrž požaduje začlenění rozhodnutí, respektive pragmatiky a lidských možností vůbec, do epistemologie. ${ }^{29}$ Pojem „rozhodnutí“ (Entscheidung) zde reprezentuje obecněji jednak popperovský kontext objevu, tj. „subjektivní zkušenosti nebo naše pocity či přesvědčení, které nikdy nemohou nějaké tvrzení odůvodnit“, jednak samozřejmě involvuje i partikulární rozhodnutí ohledně pravdivosti základních tvrzení v rámci popperovského kontextu zdůvodnění. ${ }^{30}$ Jak uvidíme, Albert se tímto strukturovaným uchopením problému (subjektivního) rozhodnutí snaží překonat nejen ostrou distinkci mezi (dle Poppera nepřekonatelně psychologickým) kontextem objevu a (dle Poppera výhradně logickým) kontextem zdůvodnění, nýbrž nadto i propast mezi subjektivním rozhodnutím a rádoby objektivním či logickým poznáním. Zásadním kritériem pro něj není logická dedukovatelnost poznání, nýbrž ,,pouze“ racionální kritizovatelnost, kterou lze aplikovat i na rozhodnutí.

Na rozdíl od Poppera se totiž Albert nesoustředí pouze na logickou analýzu metody vědy, nýbrž na mnohem obecnější problém racionality, který podle něj není pouze formálním, nýbrž též pragmatickým problémem. Tak už například sama volba mezi principem dostatečného zdůvodnění a principem kritického zkoušení, tzn. přijetí určité metody, je podle Alberta volbou-rozhodnutím v oblasti pragmatiky. Začlenění pragmatiky přitom neznamená schválení naturalistického omylu, nýbrž pouze zohlednění lidských možností v metodologii lidského poznání a vůbec ve všech

\footnotetext{
${ }^{28}$ Jedinou výjimku tvoří Albertova explicitní, avšak dále nerozvedená kritika Popperovy teorie světa-3. Albert pouze konstatuje, že Popperův svět-3 je „,nenutnou a neudržitelnou konstrukcí“ (Zimmer \& Morgenstern 2011, s. 53). Podobně Herbert Keuth odmítá Popperův svět-3 jako „přebujelou ontologii“ (Keuth 1978, s. 190). Na logické nesrovnalosti Popperovy teorie světa-3 (hl. v souvislosti s kauzálním působením entit světa-3) poukazuje např. Cmorej (2003).

${ }^{29}$ Albert (1991, s. 71).

${ }^{30}$ Popper (1997, s. 23).
} 
oblastech lidského myšlení a jednání, a to na základě tzv. postulátu realizovatelnosti a tzv. postulátu kongruence s vědeckým obrazem světa. Tyto postuláty mají za cíl především ,přemostěni““ propasti mezi poznáním a rozhodnutím, proto v důsledku podle Alberta rozlišování kontextu objevu a kontextu zdůvodnění není př́liš relevantní.

Podívejme se na tento problém blíže. Jednak to byli novopozitivisté, kteří ostře oddělili vědu od metafyziky, přičemž cílem vědy podle nich mělo být objektivní poznání empiricky „daného“ - filosofie byla v tomto pojetí redukována a transformována $\mathrm{v}$ metodu logické analýzy jazyka. A jednak to byli existencialisté, kteří takovéto formální a hodnotově neutrální vědecké poznání odsuzovali pro jeho povrchnost a soustředili svoji pozornost na hlubší filosofický vhled do podstaty existence člověka, který mělo zprostředkovat subjektivní a angažované existenciální rozhodnutí. Podle Alberta tak přes všechny rozdíly novopozitivisté i existencialisté prohloubili propast mezi ,poznáním“ (Erkenntnis) a „rozhodnutím“ (Entscheidung), to jest mezi teoretickým a praktickým rozumem, mezi bytím (tím, co je) a povinností (tím, co má být), mezi věcnou deskriptivní analýzou a normativním hodnocením.

Dichotomie objektivně racionálního poznání a subjektivně iracionálního rozhodnutí je však podle Alberta zcela „,neadekvátní, a to již proto, že za každým poznáním - vědomě či nevědomě - stojí rozhodnutí“. ${ }^{31}$ Velmi úzce to souvisí s problémem, na který poukázal již Hume. I když Albert považuje Humův zákon (z deskriptivních výpovědí nelze vyvodit výpovědi normativní) za platný, rozhodně to podle něj neznamená, že ,poznání určitých věcných souvislostí nemůže mít žádné konsekvence pro normativní přesvědčení“. ${ }^{32}$ Proto Albert zavádí takzvané přemost'ovací principy: prvním je postulát realizovatelnosti, který apeluje na to, abychom své teorie či hypotézy formulovali sohledem na to, co je pro nás realizovatelné, co je pro nás v naší konkrétní situaci reálné a možné udělat; druhým je postulát kongruence, který požaduje, aby se naše teoretické konstrukce shodovaly s vědeckým obrazem světa. Tyto postuláty slouží „kritice nerealizovatelných požadavků ve všech oblastech, také např́iklad v oblasti poznání‘33 a především úzce souvisejí s jedním ze základních předpokladů Albertova kritického racionalismu, s kritickým realismem, podle něhož existuje jen jedna skutečnost či realita, která je nezávislá na našem myšlení, zároveň je pro nás do určité míry poznatelná a umožňuje, aby naše teorie ztroskotávaly na povaze této skutečnosti. Významným faktem, který do velké míry poskytuje oprávnění pro postulát kongruence, je, že tato na nás nezávislá skutečnost dosud byla a stále je nejúspěšněji poznávána prostřednictvím vědy. Hlavní hnací silou pokroku poznání ve vědách by proto podle Alberta měl být „,zájem

\footnotetext{
${ }^{31}$ Albert (1991, s. 73).

${ }^{32}$ Albert (2000, s. 44). Srv. k tomu Paitlová (2013).

${ }^{33}$ Zimmer \& Morgenstern (2011, s. 41).
} 
o poznání skutečných souvislostí, o zlepšení našeho vědění o realitě, k níž my sami jako poznávající a jednající patříme“" ${ }^{34}$

Na základě výše uvedeného by mělo být zřejmé, proč Albert neakceptuje ostrou demarkaci poznání a rozhodnutí, nebot' je považuje za komplementární procesy: rozhodnutí (či hodnocení) je totiž součástí poznání a zároveň je racionálně kritizovatelné.

Zadruhé: Kontext zdůvodnění. K problému kontextu zdůvodnění Albert říká (stejně jako Popper), že v rámci kritického racionalismu nejde v této souvislosti „o ospravedlnění výroků a systémů výpovědí, nýbrž o jejich kritické zkoumání““. ${ }^{35}$ Albert navíc specificky upravuje a rozvádí Popperem pouze zmíněné Friesovo trilema. ${ }^{36}$ Nazývá jej Münchhausenovým trilematem, které souvisí s problémem posledního zdůvodnění poznání, tzn. s hledáním bezpečného základu a jeho absolutního zdůvodnění neboli tzv. archimédovského bodu voblasti poznání. Albert v této souvislosti připomíná známý axióm ,starých knih o logice“, větu o dostatečném důvodu (principium rationis sufficiencis), který sice z učebnic logiky zmizel, ale přetrval jako „Všeobecný postulát klasické metodologie racionálního poznání: hledej vždy dostatečné zdůvodnění pro všechna svá přesvědčení““ ${ }^{37}$ Tento postulát je zdánlivě nevinný a zdá se být samozřejmý.

Albert jej však analyzuje v rámci formální logiky jako problém logického odvození. Poukazuje prritom na tři fakta: zaprvé, že „logickou dedukcí nelze nikdy získat obsah“; zadruhé, že „platný deduktivní argument nevypovídá nic o pravdivosti jeho komponent“", nýbrž garantuje pouze transfer pozitivní pravdivostní hodnoty a zpětný transfer negativní pravdivostní hodnoty; a zatřetí, že „,neplatný deduktivní argument vytváří chybný závěr, kde tato garance není dána“. ${ }^{38}$ Přiznává, že myšlenka zdůvodnění přesvědčení rekursem na jisté základy (tj. zdůvodnění množiny výroků prostřednictvím logických dedukcí všech komponent dotyčné množiny výroků) je zajisté velmi lákavá. Avšak dodává, že pokud by tento princip byl vzat vážně, vedlo by to k zásadnímu problému:

\footnotetext{
${ }^{34}$ Albert (1987, s. 166).

${ }^{35}$ Albert (1991, s. 46).

${ }^{36}$ Srv. Friesovo trilema: „dogmatismus vs. nekonečný regres vs. psychologismus“ (Popper 1997, s. 82). V Albertově pojetí spadá dogmatismus a psychologismus nakonec vjedno, nebot' dogmatické přerušení zdůvodňovacího procesu má v zásadě „svévolný charakter“ (Albert 1991, s. 36). Své trilema proto Albert doplňuje logickým kruhem, který Fries i Popper opomněli a který vzniká proto, ,že se ve zdůvodňovacím procesu zpětně vztahujeme na výroky, které se vyskytují dříve jako nutně zdůvodnitelné“ (Albert 1991, s. 15).

${ }^{37}$ Albert (1991, s. 11).

${ }^{38}$ Albert (1991, s. 13-14).
} 
„Pokud se bude požadovat zdůvodnění všeho, pak se musí také požadovat zdůvodnění pro poznatky, na nichž spočívají názory, respektive dotyčné množiny výroků, které mají být zdůvodněny. ‘39

To vede k takzvanému Münchhausenovu trilematu, to jest k paradoxní situaci, která může mít tři varianty.

První alternativou je nekonečný regres, kdy jde požadavek zdůvodnění při hledání jistých základů stále nazpět. Na každou zdůvodňující odpověd’ následuje další otázka „a proč“ a tak to jde donekonečna. Tímto způsobem je zrrejmě hledání jistého základu, posledního zdůvodnění neboli archimédovského bodu neproveditelné. Druhou alternativou je logický kruh, kdy se v rámci procesu zdůvodnění vztahujeme na výroky, které se vyskytují dříve jako samy potřebující zdůvodnění. Zjednodušeně řečeno se jedná o svízelný problém, když se snažíme odpovědět na otázku, co bylo dřív, jestli slepice nebo vejce. Zdůvodňovací proces se v tomto případě točí v kruhu a je zcela nerozhodnutelný. Poslední, třetí alternativou je přerušení zdi̊vodňovacího procesu $v$ určitém bodě a stanovení tohoto bodu jako archimédovského. Právě tento postup lze provést nejsnáze a je většinou uplatňován: určitý bod (jako např. cogito, empirické dané) je stanoven za jistý základ poznání, který dále nepotřebuje zdůvodnit a na němž je postaveno veškeré další poznání. Albert ovšem poukazuje na to, že takovéto přerušení zdůvodňovacího procesu poznání vede de facto k suspendování principu dostatečného zdůvodnění poznání. Přerušení zdůvodňovacího procesu je většinou argumentováno samoevidencí, jistou pravdou, tím, že další zdůvodnění prostě není nutné. Albert se ale nenechává zmást a všechny podobné důvody označuje za rezignační řě̌ení a především za dogmatismus, který je z kriticko-racionálního hlediska naprosto nepřijatelný.

Albert totiž zdůrazňuje, že veškeré odvolávání se na samoevidenci a podobné samozvané ,jistoty“ je pouze alibismus a že klíčovou roli v přerušení zdůvodňovacího procesu hraje jednoduše naše rozhodnutí. Dodává, že tomuto rozhodnutí o přerušení zdůvodňovacího procesu v zásadě nelze odejmout „svévolný charakter“ a tvrdí, že „Všechny jistoty v poznání jsou autofabrikované, a proto jsou pro uchopení skutečnosti bezcenné“. 40 Navíc poukazuje na skutečnost, že takový dogmatismus je spojen imunizací svých „,nezpochybnitelných“ principů, které jsou tím uměle chráněny před jakoukoli kritikou, což vede k nežádoucí stagnaci poznání. A konečně kritizuje spojení snahy o jistotu s hledáním pravdy, což je podle něj v rámci kritického racionalismu, jenž zahrnuje konsekventní falibilismus, neakceptovatelné.

Namísto rádoby „posledních“ jistot v poznání požaduje Albert konstrukci hypotéz a jejich následnou kritiku v myšlenkových i reálných experimentech. Proto tvrdí:

\footnotetext{
${ }^{39}$ Tamtéž, s. 15.

${ }^{40}$ Tamtéž, s. 36.
} 
„Dosadíme-li na místo ideje posledního zdůvodnění ideu kritického zkoušení, tedy ideu kritické diskuze všech výroků, které přicházejí v úvahu, pomocí racionálních argumentů, tak se sice zříkáme jistot, jež sami produkujeme, avšak máme vyhlídku, že se přiblížíme k pravdě. “41

A právě to je důsledek odmítnutí požadavku posledního zdůvodnění poznání: na jedné straně nejistota, na straně druhé vyhlídka vyšší aproximace k pravdě. Princip kritického zkoušení tedy nevede ke skepsi či destrukci poznání, nýbrž v důsledku usiluje o kritiku, která má ve smyslu racionální heuristiky vést k pokroku poznání. Proto tvrdí, že „poznání se pohybuje mezi konstrukcí a kritikou“ a dodává, že ,,je to součást lidské praxe, ve které musí být neustále činěna rozhodnutí“. ${ }^{42}$ Tím se opět dostávám k problému ,propasti“ mezi rozhodnutím a poznáním, resp. mezi kontextem objevu a kontextem zdůvodnění. Na základě výše uvedených důvodů může Albert konstatovat:

„Rozlišení mezi kontextem objevu a zdůvodnění v poznání, a s tím spojená dichotomie mezi logikou vědy na jedné straně a historií, sociologií a psychologií vědy na straně druhé, nelze při zohlednění skutečných kvalit poznávací situace udržet. “43

V této části bylo představeno Albertovo uchopení problému zdůvodnění, které je víceméně kongruentní s Popperovým chápáním kontextu zdůvodnění, ovšem představuje výrazné rozpracování tzv. Münchhausenova trilematu. V jistém smyslu lze také Albertovu tezi, že za každým poznáním stojí rozhodnutí, najít u Poppera, který však rozhodnutí (ve smyslu kontextu objevu) nezahrnuje do své koncepce logiky vědy, která se soustředí výhradně na kontext zdůvodnění. Jak je z výše uvedeného zřejmé, Albert se neomezuje toliko na logiku vědy, nýbrž snaží se načrtnout komplexní teorii poznání. Předpoklady a postuláty své teorie poznání pak Albert vztahuje i na vědeckou praxi. Odmítá proto ostré rozlišování kontextu objevu a kontextu zdůvodnění jako pro vědeckou praxi irelevantní. Právě v této oblasti pak Albert podle mého názoru Poppera svým způsobem překonává, což ukážu v následující části této stati.

\section{Od kontextu zdůvodnění ke kontextu aplikace}

Již bylo několikrát zdůrazněno, že Popperova koncepce kritického racionalismu je zaměřena $v$ první řadě na logiku vědy a soustředí se na problémy indukce a demarkace $v$ rámci kontextu zdůvodnění, přičemž se snaží vymezit vůči novopozitivistické metodě verifikace založené právě na principu indukce a vůči novopozitivistickému odmítnutí

\footnotetext{
${ }^{41}$ Tamtéž, s. 42.

${ }^{42}$ Tamtéž, s. 65.

${ }^{43}$ Albert (1978, s. 49).
} 
metafyziky. ${ }^{44}$ Také již bylo ukázáno, že Albert ve svém Traktátu rozpracovává některé problémy, které Popper jen naznačil a zároveň ho v některých ohledech překonává (zahrnutí kontextu objevu). Jiné (problém indukce a problém demarkace) ponechává stranou, přičemž není jisté, zda je to proto, že je považoval za Popperem dostatečně vyřešené, nebo proto, že jim nepřikládal význam.

Alespoň co se problému demarkace týče, lze se oprávněně domnívat, že Albert jej zřejmě nepovažuje za podstatný. Již byla řeč o postulátech realizovatelnosti a kongruence, $\mathrm{k}$ nimž se přidává postulát jednotné metody vědy a předpoklad teoretického pluralismu a konstruktivní metafyziky. K postulátu jednotné metody vědy se dostanu vzápětí, nyní krátce vysvětlím Albertův předpoklad teoretického pluralismu a konstruktivní metafyziky. Teoretický pluralismus spočívá v

„hledání alternativ, hledání jiných teorií, které jsou možná lepší, nebot' mají větší vysvětlovací sílu, vyhýbají se určitým omylům a překonávají různé těžkosti, které dosavadní teorie nebyly schopny zvládnout““ 45

Alternativní teorie totiž může vést k experimentům, které mohou zpochybnit stávající teorii a podpořit jinou, alternativní hypotézu, což se podle Alberta rozhodně vyplatí, nebot' to zásadně přispívá k pokroku poznání. Konstruktivní metafyzika je metafyzika právě ve smyslu teoretické alternativy, která mírí na radikální proměnu současného stavu poznání, čímž by opět měla zároveň přispívat k jeho pokroku. Metafyzika ve smyslu alternativní hypotézy může ,tvrdit nemožné, to znamená: navrhnout možnosti, které nejsou dle současného stavu vědy dané, aniž by existoval důvod, tyto možnosti předem odmítnout“. ${ }^{46}$ Pokud má ovšem metafyzika přispět k pokroku poznání, může sice v zásadě tvrdit „nemožné“, ale v důsledku je třeba ji „podrobit realistické kritice, tedy rozvinout ji tak dalece, že může dostat př́ležitost ztroskotat na povaze reality“ “. ${ }^{47}$

S tím navíc souvisí postulát jednotné metody vědy. Jedná se o požadavek, aby metody všech věd - prrírodních i duchovních - vycházely ze stejné obecně metodologické báze, a to báze reálné. Vzhledem k tomu, že cílem všech věd by měla být aproximace $\mathrm{k}$ pravdě či $\mathrm{k}$ realitě, měla by také jejich metoda $\mathrm{v}$ tom nejobecnějším smyslu vycházet $\mathrm{z}$ reálné báze. $\mathrm{Z}$ tohoto hlediska by podle Alberta neměl být činěn rozdíl mezi vědami přirodními a duchovními - aby mohly dostát statutu „vědecké“, musí jak přírodovědné, tak duchovědné teorie mít charakter pouze informativně deskriptivních výpovědí bez normativních nároků. ${ }^{48}$ Čistě informativní teorie jsou často úspěšně prakticky použitelné, přičemž pro jejich aplikaci je rozhodující informační

\footnotetext{
${ }^{44}$ Ale srv. např. osobité pojetí pozitivismu českého filosofa Josefa Tvrdého, který v rámci svého pozitivisticky orientovaného myšlení metafyziku neodmítá. Viz např. Kratochvíl (2014).

${ }^{45}$ Albert (1991, s. 59).

${ }^{46}$ Tamtéž, s. 60-61.

${ }^{47}$ Tamtéž, s. 61. K metodologickým východiskům Albertova kritického racionalismu více viz Paitlová (2015).

${ }^{48}$ K Albertově řešení problému hodnotové neutrality vědy viz Paitlová (2013).
} 
obsah a relevance pro řešení dotyčných praktických problémů. Onu relevanci by nám měla pomoci určit konsekventní racionální kritika. V této souvislosti zdůrazněme, že Albert přiznává vědeckým teoriím nejen konjekturální, nýbrž $\mathrm{v}$ důsledku též doporučující charakter. Tím se však zásadně odlišuje od Popperova striktně zákazového charakteru vědeckých teorií. $^{49}$

Kriticistické teorii vědy proto

„,nezáleží na tom, aby ve vědách legitimizovala status quo, tedy: ospravedlnila stávající hranice, vědecké oblasti, metody a řešení problémů, nýbrž aby přispěla ke zlepšení poznávací praxe ve vědách““. 50

V obecné metodologické bázi by proto jednotícím zájmem všech věd měl být zájem o poznání reálných souvislostí, o zlepšení našeho vědění o realitě. Navíc všechny výše zmíněné postuláty (realizovatelnosti, kongruence a jednotné metody vědy) spolu s předpoklady teoretického pluralismu a konstruktivní metafyziky Albertovi umožňují překonat požadavek samotného demarkačního kritéria, na němž lpěli jak pozitivisté, tak Popper. Podle Alberta by měl princip kritického zkoušení být obecnou metodologickou bází nejen všech věd, nýbrž nadto vůbec všech lidských řešení problémů (například i politiky, ekonomiky, náboženství, etiky etc.). A nadto se nejedná pouze o zákazy (jako u Poppera), ale o doporučení, jak postupovat v praxi.

Ačkoli to Albert, alespoň pokud vím, nikde explicitně nezmiňuje, vztahuje se podle mého názoru jeho řešení statutu vědecké teorie a metodologie jako takové k problému třetího možného kontextu, a to kontextu aplikace vědecké teorie. Někteří autoři $^{51}$ zařazují tuto problematiku do kontextu objevu, s čímž však nesouhlasím. Podle Alberta je totiž třeba zachovávat hodnotovou neutralitu (či objektivitu) vědy, to znamená, striktně rozlišovat mezi informativní technologií, to jest dotyčným systémem výpovědí, který by měl být hodnotově neutrální (patří tedy spíše do kontextu zdůvodnění), a aplikovanou technikou, to jest použitím dotyčného systému výpovědí v praktickém životě (což evidentně tematizuje kontext aplikace). Albert apeluje na to, abychom nezaměňovali relevanci technologických systémů pro řešení určitých problémů s legitimací pro jejich praktické použití. Technologické systémy totiž nemají normativní charakter, což znamená, že neodpovídají na otázku Co bychom měli dělat? nýbrž v intenci postulátu realizovatelnosti odpovídají pouze na otázku Co můžeme učinit, pokud řšsime ty a ty problémy? - neobsahují žádné předpisy, nýbrž pouze informace o lidských možnostech jednání a působení, a právě v tom spočívá jejich praktický význam. ${ }^{52}$

${ }^{49}$ Srv. „Ne pro nic za nic nazýváme př́rodní zákony ,zákony“: čím více zakazují, tím více říkají.“ (Popper 1997, s. 20).

${ }^{50}$ Albert (2011, s. 56).

${ }^{51}$ Např. Gadenne (1996).

${ }^{52}$ Srv. Albert (2000, s. 52). 
Nadto již Popper ve své Logice vždy zdůrazňuje návrhový charakter tvrzení. Podle něj ,nemohou být ve vědě žádná konečně platná tvrzení“.53 A to platí i pro samotnou filosofii vědy: poukažme na fakt, že i svoji metodu falsifikace označuje Popper pouze jako „návrh na dohodu či konvenci““. ${ }^{54}$ To je velmi podstatný moment a zásadní charakteristický rys kritického racionalismu vůbec. Také podle Alberta je podstatou kriticistického přístupu právě dočasnost a pouhý návrhový či hypotetický charakter veškerých (nejen vědeckých) tvrzení a teorií, a to jak v rovině „horizontální“, tedy v oblasti tvrzení, která jsou prizmatem kritického racionalismu zkoumána, tak v rovině „vertikální“, to jest v rámci metodologických východisek samotného kritického racionalismu. Proto stejně jako Popper i Albert explicitně přiznává, že kritický racionalismus je též pouze hypotéza, která ,,je otevřená kritické argumentaci a nemůže si pro sebe nárokovat žádnou jistotu“. ${ }^{55}$ Albert nadto explicitně postuluje kritický racionalismus jako návrh způsobu života. ${ }^{56}$

\section{Závěr}

Albertovo řešení problému kontextů objevu, zdůvodnění a aplikace vědecké teorie pokládám z výše uvedených důvodů za komplexnější než eliminační řešení Popperovo. Ačkoli je Popperova teorie poznání v omezení se na logiku vědy zajisté logicky preciznější, je tomu tak za cenu mnohých redukcí, které se nezdají být z pohledu kritického racionalismu žádoucí a - jak ukázal Albert - nejsou ani nutné. Proto za důležitý Albertův př́nos považuji především jeho přemostění propasti mezi (subjektivním) rozhodnutím a (objektivním) poznáním, tedy překonání ostrého ohraničení výše zmíněných dvou, respektive tří kontextů prostřednictvím postulátů realizovatelnosti a kongruence. Ty - spolu s postulátem jednotné metody vědy a předpokladem teoretického pluralismu a konstruktivní metafyziky - umožňují Albertovi překonat též požadavek ostrého demarkačního kritéria (na němž lpěli jak pozitivisté, tak Popper), nebot' podle něj by měl princip kritického zkoušení být obecnou metodologickou bází nejen všech věd (přírodních i humanitních), nýbrž nadto vůbec všech lidských řešení problémů. Obecný závěr této stati (který je doložen již v úvodní citaci) lze zformulovat tak, že Albert velmi vnímavě - to znamená: v popperovských intencích - filosoficky rozšiřuje a systematizuje kriticko-racionalistickou teorii poznání.

\footnotetext{
${ }^{53}$ Popper (1997, s. 27).

54 Tamtéž, s. 16. Zároveň Popper dodává: „Nakolik mohu vidět, je jen jedna cesta, jak racionálně argumentovat na podporu mých návrhů. Totiž analyzovat jejich logické důsledky: ukázat jejich plodnost - jejich sílu osvětlovat problémy teorie poznání.“ (Popper 1997, s. 16) I zde si všimněme oněch vlastní tvrzení částečně oslabujících výrazů „nakolik“ a „návrhů“.

${ }^{55}$ Albert (1991, s. 224).

${ }^{56} \mathrm{~K}$ problematice kritického racionalismu jako návrhu způsobu života viz Paitlová (2014).
} 


\section{Literatura}

Albert, H. (2011): Kritische Vernunft und rationale Praxis. Mohr Siebeck, Tübingen.

Albert, H. (2000): Kritischer Rationalismus. Vier Kapitel zur Kritik illusionären Denkens. Mohr Siebeck, Tübingen.

Albert, H. (1991): Traktat über kritische Vernunft. Mohr Siebeck, Tübingen.

Albert, H. (1987): Kritik der reinen Erkenntnislehre. Das Erkenntnisproblem in realistischer Perspektive. Mohr Siebeck, Tübingen.

Albert, H. (1978): Traktat über rationale Praxis. Mohr Siebeck, Tübingen.

Cmorej, P. (2003): „Popperov svet 3.“ In Metoda-význam-intence. Popperovské motivy v současném analytickém myšlení, ed. V. Havlík, FILOSOFIA, Praha, 2003, s. 11-22.

Funda, O. A. (2015): „Racionalita a existence.“ Philosophica Critica 1 (2): 53-82.

Gadenne, V. (1996): „Rationale Heuristik und Falsifikation.“ In Rationalität und Kritik, eds. V. Gadenne \& H. J. Wendel, Mohr Siebeck, Tübingen, 1996, s. 57-78.

Grattan-Guinness, I. (2004): „Karl Popper and the 'The Problem of Induction': A Fresh Look at the Logic of TestingScientific Theories.“ Erkenntnis 60 (1): 107-120.

Hahn, R. (1982): Die Theorie der Erfahrung bei Popper und Kant. Zur Kritik des Kritischen Rationalismus am transzendentalen Apriori. Verlag Karl Alber, Freiburg / München.

Keuth, H. (1978): Realität und Wahrheit. Zur Kritik des kritische Rationalismus. Mohr Siebeck, Tübingen.

Kratochvíl, M. (2014): Pozitivismus v české filosofii první poloviny 20. století. Západočeská univerzita v Plzni, Plzeň.

Morgenstern, M. \& Zimmer, R. (2005): Hans Albert / Karl Popper Briefwechsel. Fischer Taschenbuch Verlag, Frankfurt am Main.

Niemann, H.-J. (2006): Lexikon des Kritischen Rationalismus. Mohr Siebeck, Tübingen.

Parusniková, Z. (2009): „Epistemologie K. R. Poppera a darwinistický výklad růstu vědění.“ In Evoluce a věda, eds. J. Nosek \& V. Havlík, OPS, Nymburk, 2009, s. 63-79.

Parusniková, Z. (2007): Rozum, kritika, otevřenost. Živý odkaz filosofie K. R. Poppera. FILOSOFIA, Praha.

Parusniková, Z. (2003): „Vyřešil K. R. Popper psychologický problém indukce.“ In Metoda - význam - intence. Popperovské motivy v současném analytickém myšlení, ed. V. Havlík, FILOSOFIA, Praha, 2003, s. 55-65.

Paitlová, J. (2015): „Metodologická východiska kritického racionalismu Hanse Alberta.“ Filosofický časopis 63 (4): 561-580. 
Paitlová, J. (2014): „Hans Albert: Kritický racionalismus jako návrh způsobu života.“ Filosofie dnes 6 (2): 43-63 [online]. 2014, [cit. 20. 3. 2016]. Dostupné z: <http://filosofiednes.ff.uhk.cz/index.php/hen/article/view/176/144>

Paitlová, J. (2013): „Hans Albert a problém hodnotové neutrality vědy.“ Teorie vědy 35 (3): 381-396 [online]. 2013, [cit. 20. 3. 2016]. Dostupné z: <http://teorievedy.flu.cas.cz/index.php/tv/article/view/215/242>

Popper, K. R. (2009): Vermutungen und Widerlegungen. Das Wachstum der wissenschaftlichen Erkenntnis. Mohr Siebeck, Tübingen.

Popper, K. R. (1997): Logika vědeckého zkoumání. OIKOYMENH, Praha.

Popper, K. R. (1995): Věčné hledání. Intelektuální autobiografie. Vesmír - Prostor OIKOYMENH, Praha.

Popper, K. R. (1993): Objektive Erkenntnis. Ein evolutionärer Entwurf. Hoffman und Campe, Hamburg.

Preston, J. (1994): „Methodology, Epistemology and Conventions: Popper's Bad Start.“ Proceedings of the Biennial Meeting of the Philosophy of Science Association 1: 314322.

Rivadulla, A. (1987): „Kritischer Realismus und Induktionsproblem.“ Erkenntnis 26 (2): 181-193.

Sloup, O. (2015a): „Frustrace ve vědecké praxi.“ Teorie vědy 37 (1): 77-95 [online]. 2015, [cit. 20. 3. 2016]. Dostupné z:

<http://teorievedy.flu.cas.cz/index.php/tv/article/view/274/304>

Sloup, O. (2015b): „Kritické zhodnocení Popperova řešení problému indukce.“ Antropowebzin (3-4): 117-126 [online]. 2015, [cit. 3. 6. 2016]. Dostupné z: <http://www.antropoweb.cz/webzin/index.php/webzin/article/view/216/224>.

Zimmer, R. \& Morgenstern, M. (2011): Gespräche mit Hans Albert. LIT Verlag, Münster. 